\title{
Pengaruh Organizational Culture terhadap Employee Engagement dengan Job Satisfaction sebagai Variable Intervening pada Karyawan PT Pelindo III (Persero)
}

\author{
Rm. Kumara Anindhita Widyaswendra \\ Universitas Airlangga \\ e-mail: Widyas.Wendra@pelindo.co.id
}

\begin{abstract}
This study aims to examine the effect of organizational culture on employee engagement with job satisfaction as an intervening variable on the employees of PT Pelindo III (Persero). The data analysis technique used in this study uses partial least square. The sample used was 210 respondents of PT Pelindo III (Persero) employees located in Surabaya. The results showed that organizational culture influences employee engagement, job satisfaction influences employee engagement, and organizational culture influences employee engagement with job satisfaction as an intervening variable. The results obtained indicate that there is no direct and insignificant influence between organizational culture and employee engagement, so it seems clear that job satisfaction fully mediates the effect of organizational culture on employee engagement. From the results of research at PT Pelindo III shows organizational culture, employee engagement and Job Satisfaction are appropriate, but there are several factors that are continuously being improved, including maintaining the opportunity for self-development opportunities in jobs that occupy the highest category of other factors, given the majority of PT Pelindo III employees is a millennial generation so programs must be found to suit their interests.
\end{abstract}

Keywords: organizational culture, job satisfaction, employee engagement

\section{PENDAHULUAN}

Konsep engagement telah menjadi determinan penting bagi kesuksesan organisasi terkait kualitas, efisiensi, dan produktivitas (Macey dan Scheneider, 2008). Ketatnya persaingan bisnis saat ini menyebabkan perusahaan yang pada awalnya hanya melakukan recruitment, mengembangkan karyawan, dan mempertahankan karyawan yang berpotensi, kini juga harus mampu membuat karyawannya memiliki engagement terhadap pekerjaan dan perusahaan mereka sehingga produktivitas karyawan juga akan meningkat (Sunyoto, 2015).

Pengukuran employee engagement telah dilakukan di berbagai perusahaan di seluruh dunia pada beberapa tahun terakhir. Hewitt (2016) menyatakan bahwa saat ini di seluruh dunia perusahaan-perusahaan yang menggunakan pengukuran mengenai employee engagement terus mengalami peningkatan meskipun berada di tengah-tengah ketatnya kondisi pasar tenaga kerja di United States, ketidakpastian kondisi ekonomi di negara-negara Eropa, dan tantangan-tantangan bisnis yang dihadapi negara-negara lain.

Banyak penelitian yang berusaha menggunakan konsep engagement secara mendalam. Para akademisi berusaha menemukan faktor-faktor yang terkait engagement dengan harapan dapat digunakan sebagai dasar untuk mengelola karyawannya sesuai dengan tujuan perusahaan. Salah satu faktor yang memengaruhi adalah faktor organizational culture (Leung dan Wijaya, 2016).

Organizational culture merupakan sebuah sistem yang ada di perusahaan yang dianut oleh 
anggotanya. Budaya perusahaan adalah suatu sistem nilai-nilai yang dirasakan oleh seluruh orang yang ada dalam organisasi (Robbins dan Judge, 2008). Selain dipahami seluruh jajaran meyakini sistem-sistem nilai tersebut sebagai landasan gerak organisasi. Organizational culture mewakili sebuah persepsi yang sama dari para anggota organisasi. Oleh karena itu, diharapkan bahwa individu-individu yang memiliki latar belakang berbeda atau berada pada tingkatan yang tidak sama dalam organisasi dapat memahami organizational culture dengan pengertian yang serupa.

Pada PT Pelindo III (Persero), untuk mewujudkan visi, misi, serta tujuan yang telah ditetapkan, manajemen perusahaan menyadari perlunya dukungan organizational culture yang selaras dengan karakteristik bisnis, lingkungan bisnis, dan strategi Perusahaan yang telah terumuskan. Budaya yang dimaksud perlu dimiliki oleh seluruh karyawan perusahaan serta terinternalisasi dengan baik di setiap proses bisnis perusahaan. Nilai inti perusahaan adalah customer focus, care dan integrity.

Faktor lain yang menjadi anteseden dari employee engagement yaitu job satisfaction yang dapat dijabarkan sebagai suatu perasaan yang menyenangkan atau positif yang merupakan hasil dari penilaian atas pekerjaan atau pengalaman seseorang (Luthans, 2005). Dari pendapat tersebut dapat dijelaskan bahwa kepuasan diperoleh setelah karyawan menjalankan sebuah proses kerja. Ketika karyawan menjalankan tugasnya sebagai karyawan, sang karyawan akan mengalami proses kerja yang akan membuatnya puas apabila pekerjaan tersebut memenuhi syaratsyarat atau harapan yang dipersepsikan sang karyawan di awal sebelum pekerjaannya dimulai.

Pelindo III berupaya menciptakan nilai tambah yang berkelanjutan untuk peningkatan kepuasan stakeholder, memberikan kenyamanan dan kemudahan bagi pelanggan, serta menciptakan solusi bisnis yang cerdas melalui integrasi dan kerjasama dengan mitra strategis. Untuk mencapai visi dan misi tersebut Pelindo III menyusun strategi-strategi yang dituangkan dalam Rencana Jangka Panjang Perusahaan (RJPP), serta fokus pada perubahan untuk keberlanjutan.

Agar visi dan misi tersebut tercapai tidak hanya dibutuhkan strategi yang jelas saja, namun tidak kalah pentingnya juga harus didukung oleh SDM yang memiliki employee engagement yang tinggi dengan perusahaan, karena karyawan yang terikat dengan perusahaan akan merasa sangat terlibat dengan keberlangsungan dan kesuksesan perusahaan, employee engagement sangat dipengaruhi oleh organizational culture yang kuat mengakar dari atas sampai dengan bawah lini organisasi (Wibowo dan Putra, 2016). Untuk itu, Pelindo III memiliki nilai-nilai perusahaan yang menjadi acuan dan norma dalam berperilaku dan bertindak sehingga menjadi organizational culture yang kuat, yaitu: customer focus, care, dan integrity.

Pengelolaan sumber daya manusia di PT Pelindo III (Persero) perlu dilakukan secara baik dan terencana, di antaranya dengan melakukan evaluasi job satisfaction dan employee engagement agar kinerja dan pelayanan perusahaan kepada para pelanggannya terus meningkat, dan pada gilirannya meningkat pula keuntungan perusahaan dan kesejahteraan karyawannya. Apabila job satisfaction telah mencapai level tertinggi maka akan timbul sikap employee engagement terhadap perusahaan. Oleh karena itulah organisasi perlu untuk memperhatikan tingkat employee engagement karyawannya. Kepedulian terhadap tingkat employee engagement yang ada di dalam lingkungan kerja merupakan hal yang sangat penting (Seijts dan Crim, 2006) karena employee engagement terbukti memiliki kontribusi terhadap kesuksesan sebuah organi- 
Rm. Kumara Anindhita Widyaswendra, Pengaruh Organizational Culture terhadap Employee Engagement dengan Job Satisfaction sebagai Variable Intervening pada Karyawan PT Pelindo III (Persero)

sasi dalam menjalankan bisnis dan employee engagement dipengaruhi organizational culture.

Tabel 1.1 Survei Kepuasan Pegawai Tahun 2018

\begin{tabular}{|c|c|c|c|c|c|c|c|}
\hline No & Unit Kerja & $\begin{array}{c}\text { Jumlah } \\
\text { Responden }\end{array}$ & Skor & $\begin{array}{c}\text { Jumlah } \\
\text { Nilai }\end{array}$ & $\begin{array}{l}\text { Jumlah } \\
\text { Nilai } \\
\text { Tertinggi }\end{array}$ & $\underset{\text { ex }}{\text { \%Ind }}$ & $\underset{\mathrm{i}}{\text { Interpretas }}$ \\
\hline 1 & $\begin{array}{l}\text { Kantor Pusat } \\
\text { ( Surabaya) }\end{array}$ & 320 & 4.31 & 23446 & 27200 & 86.20 & $\begin{array}{l}\text { Sangat } \\
\text { Puas }\end{array}$ \\
\hline 2 & Regional Jatim & 469 & 4.54 & 36225 & 39865 & 90.87 & $\begin{array}{l}\text { Sangat } \\
\text { Puas }\end{array}$ \\
\hline 3 & Regional Jateng & 329 & 4.53 & 25309 & 27965 & 90.50 & $\begin{array}{l}\text { Sangat } \\
\text { Puas }\end{array}$ \\
\hline 4 & $\begin{array}{l}\text { Regional } \\
\text { Kalimantan }\end{array}$ & 300 & 4.39 & 22387 & 25500 & 87.79 & $\begin{array}{l}\text { Sangat } \\
\text { Puas }\end{array}$ \\
\hline 5 & $\begin{array}{l}\text { Regional Bali } \\
\text { Nusra }\end{array}$ & 161 & 4.32 & 11827 & 13685 & 86.42 & $\begin{array}{l}\text { Sangat } \\
\text { Puas }\end{array}$ \\
\hline 6 & Korporat & 1579 & 4.44 & 119194 & 134215 & 88.81 & $\begin{array}{l}\text { Sangat } \\
\text { Puas }\end{array}$ \\
\hline
\end{tabular}

Sumber: Laporan survei kepuasan dan engagement pegawai tahun 2018

Dari data di atas, secara korporat hasil survei kepuasan pegawai tahun 2018 memperoleh skor 4.44 dengan interpretasi sangat puas. Dengan demikian secara umum, pegawai Pelindo 3 dapat dikatakan sangat puas dengan pekerjaan, atasan, rekan kerja, lingkungan kerja, keselamatan kerja, dan benefit yang diberikan perusahaan. Apabila dilihat berdasarkan unit kerja, regional Jawa Timur memperoleh skor job satisfaction tertinggi.

Berdasarkan hasil tersebut, terlihat bahwa kecenderungan engagement karyawan mengalami penurunan. Oleh karena itu, penelitian ini mengambil judul Pengaruh Organizational Culture Terhadap Employee Engagement dengan Job Satisfaction sebagai Variable Intervening pada Karyawan PT Pelindo III (Persero).

\section{TINJAUAN PUSTAKA}

\section{Organization Culture}

Organizational culture adalah apa yang dipersepsikan karyawan dan cara persepsi itu menciptakan suatu pola keyakinan, nilai, dan ekspektasi (Ivancevich, dkk., 2006). Sedangkan organizational culture juga mengacu ke suatu sistem makna bersama yang dianut oleh anggotaanggotanya dan yang membedakan antara satu organisasi dengan lainnya (Robbins, 2008). Wallach (1983) menjelaskan istilah budaya korporasi (corporate culture) sebagai bentuk pemahaman bersama perilaku anggota - bagaimana cara mereka bekerja dalam melakukan sesuatu. Kepercayaan-kepercayaan, nilai-nilai, norma, dan loso atau cara hidup (way of life) yang dianut individu akan menentukan bagaimana segala sesuatunya berjalan. Mereka membatasi bagaimana cara seseorang bekerja, standar tingkah laku, cara berbicara, bagaimana mempresentasikan diri, dan keharusan-keharusan apa yang perlu dipatuhi oleh seseorang.

\section{Employee Engagement}

Strom, Sears dan Kelly (2014) mengutip Bates (2004) bahwa perusahaan yang paling produktif dan fungsional terdiri dari karyawan yang sangat berharga yang secara fisik, kognitif, dan emosional terlibat dalam pekerjaan mereka. Untuk mendorong keterlibatan karyawan, organisasi harus fokus pada menumbuhkan lingkungan kerja yang mendukung karyawan, membuat mereka termotivasi dan positif, tidak hanya tentang pekerjaan mereka saja tetapi juga tentang organisasi secara keseluruhan. Dengan menawarkan kepemimpinan berkualitas tinggi dalam lingkungan kerja yang bijaksana dan teratur, organisasi dapat meningkatkan tingkat employee engagement yang diinginkan.

Menurut Kahn (1990) employee engagement adalah keterikatan karyawan terhadap organisasi dalam peran pekerjaan mereka dan karyawan menunjukkan keterikatan individu tersebut dengan mengekspresikan diri mereka secara fisik, mental, dan emosional selama bekerja. 
Aspek mental dari keterikatan berarti apa yang menjadi keyakinan karyawan terhadap organisasi dan aspek emosional berarti apa yang dirasakan karyawan dan sikap positif atau negatif karyawan tersebut terhadap organisasi dan para pemimpinnya. Sedangkan Aspek fisik dari employee engagement berarti energi fisik yang digunakan oleh karyawan untuk memenuhi peran mereka. Menurut Schaufeli, Bakker, dan Salanova dalam Abd-Allah (2016) menyimpulkan bahwa work engagement adalah kondisi pikiran yang positif, memuaskan, dan berhubungan dengan pekerjaan yang dicirikan oleh kekuatan atau semangat (vigor), dedikasi (dedication), dan absorbsi (absorption).

\section{Job Satisfaction}

Job satisfaction didefinisikan sebagai suatu perasaan positif tentang pekerjaan seseorang yang merupakan hasil dari evaluasi karakteristikkarakteristiknya (Robbins, 2008). Seseorang dengan tingkat job satisfaction yang tinggi memiliki perasaan-perasaan positif tentang pekerjaan tersebut, sementara seseorang yang tidak puas memiliki perasaan-perasaan yang negatif tentang pekerjaan tersebut. Orang yang merasa puas menganggap kepuasan sebagai suatu rasa senang dan sejahtera karena dapat mencapai suatu tujuan atau sasaran. Setiap pimpinan perusahaan perlu mengetahui informasi mengenai kepuasan karyawannya dalam bekerja secara akurat sebagai bahan pertimbangan dalam mengambil keputusan untuk memecahkan masalah yang dihadapi dalam perusahaan.

Menurut Malthis (2006) job satisfaction adalah keadaan emosi yang positif dari mengevaluasi pengalaman kerja seseorang. Ketidakpuasan kerja muncul saat harapan-harapan ini tidak terpenuhi. Job satisfaction mempunyai banyak dimensi, secara umum adalah kepuasan dalam pekerjaan itu sendiri, gaji, pengakuan, hubungan antara supervisor dengan tenaga kerja, dan kesempatan untuk maju. Setiap dimensi menghasilkan perasaan puas secara keseluruhan dengan pekerjaan itu sendiri. Secara umum diketahui bahwa job satisfaction merupakan faktor yang berkontribusi terhadap fisik dan mental kesejahteraan karyawan. Karena itu, ia memiliki pengaruh yang signifikan pada pekerjaan yang berhubungan dengan perilaku seperti produktivitas, absensi, tingkat turnover, dan hubungan karyawan.

\section{Pengaruh Organizational Culture terhadap Em-} ployee Engagement

Organizational culture yang kuat menunjukkan bahwa karyawan memegang keyakinan dan nilai-nilai etika yang sama. Ketika keyakinan dan nilai-nilai etika selaras dengan tujuan organisasi, mereka bisa efektif dalam membangun tim karena adanya hubungan dan kepercayaan membantu mereka menghindari konflik dan fokus pada penyelesaian tugas. Karyawan yang memaknai serta berkontribusi terhadap pekerjaannya dan mengerjakan pekerjaan dengan mencurahkan segenap energi fisik, kognitif, dan emosinya disebut sebagai karyawan yang engaged (Kahn, 1990 dalam Kulaar et al., 2008). Perilaku engagement yang paling terlihat jelas adalah usaha dari orang tersebut. Orang yang engaged terlihat bekerja keras, berusaha, dan terlibat penuh pada pekerjaan. Mereka fokus pada apa yang mereka kerjakan dengan mengerahkan segenap energinya (Schaufeli dan Baker, 2004 dalam Albrecht, 2010). Membangun organizational culture yang khas merupakan salah satu strategi menciptakan employee engagement yang perlu untuk diperhatikan oleh para manajer, perusahaan harus 
mempromosikan organizational culture yang kuat di mana tujuan dan nilai-nilai manajer sejajar di semua bagian pekerjaan. Perusahaan yang membangun budaya saling menghormati dengan menjaga kisah sukses hidup tidak hanya akan menjaga karyawan mereka yang engaged, tetapi juga mereka karyawan yang baru masuk dapat menularkan budaya semangat kerja (Markos dan Sridevi, 2010). Menurut McBain (2007) salah satu faktor yang mendukung terbentuknya employee engagement adalah organizational culture. Lockwood (2007) juga menyatakan bahwa organizational culture adalah salah satu faktor yang memengaruhi employee engagement. Kondisi organizational culture yang mendukung dalam pekerjaan dan perkembangan karyawan, serta kondisi kerja yang ramah dan saling membantu juga dapat membantu dalam membentuk sifat engaged terhadap pekerjaannya. Kompensasi dan keuntungan yang cukup dan sepadan juga dapat membuat karyawannya merasa engaged terhadap pekerjaannya. Hal-hal lain menyangkut organizational culture yang dapat membantu dalam pembentukan employee engagement adalah misi dan visi organisasi yang jelas, perlakuan dari anggota organisasi lainnya, kebijakan pekerjaan dan keseimbangan kerja dapat memengaruhi dalam pembentukan employee engagement. Berdasarkan hasil penelitian terdahulu (Giovanni \& Hendrika, 2013; Sopyan, 2016; dan Leung \& Wijaya, 2016) menunjukkan terdapat pengaruh yang positif dan signifikan organizational culture terhadap employee engagement.

\section{Pengaruh Organizational Culture terhadap Job Satisfaction}

Menurut Kotter dan Hesket (Sutanto, 2002: 129) mengungkapkan bahwa organizational culture yang kuat akan memicu karyawan untuk berpikir, berperilaku dan bersikap sesuai dengan nilai-nilai organisasi. Kesesuaian antara organizational culture dengan anggota organisasi yang mendukungnya akan menimbulkan job satisfaction, sehingga mendorong karyawan untuk meningkatkan kinerja menjadi lebih baik, yaitu bertahan pada satu perusahaan dan berkarier dalam jangka panjang. Oleh karena itu, organizational culture yang kuat diperlukan oleh setiap organisasi agar kepuasan karyawan meningkat. Hal tersebut selaras dengan penelitian yang dilakukan oleh Safwat, Ahmad (2015) yang menunjukkan bahwa organizational culture memiliki pengaruh positif yang signifikan terhadap job satisfaction. Penelitian tersebut juga didukung oleh penelitian yang dilakukan Ahamed dan Mahmood (2015) yang menyimpulkan bahwa organizational culture benar-benar memiliki pengaruh yang kuat dan signifikan terhadap job satisfaction.

\section{Pengaruh Job Satisfaction terhadap Employee Engagement}

Safwat, Ahmad (2015) dalam penelitiannya menyimpulkan bahwa ada hubungan positif antara variable job satisfaction dengan employee engagement, yang dapat diartikan bahwa employee engagement dapat ditingkatkan dengan meningkatkan job satisfaction karyawan. Pininta dan Indriati (2015) dalam penelitiannya juga menyimpulkan bahwa ada hubungan positif yang signifikan antara job satisfaction terhadap employee engagement, yang artinya bahwa semakin tinggi job satisfaction semakin tinggi employee engagement.

Job Satisfaction Memediasi Hubungan Organizational Culture dengan Employee Engagement 
Dalam penelitian yang dilakukan Humairoh dan Wardoyo (2017) menunjukkan terdapat pengaruh antara organizational culture terhadap employee engagement dengan job satisfaction sebagai variabel intervening. Dengan hasil ini maka dapat disimpulkan bahwa job satisfaction menjadi variabel antara organizational culture terhadap employee engagement atau adanya organizational culture dalam bekerja akan menumbuhkan rasa puas dalam bekerja dan rasa puas yang dirasakan ini akan berpengaruh terhadap terciptanya keterikatan yang baik dari para karyawan.

\section{PERUMUSAN MASALAH}

Berdasarkan uraian latar belakang permasalahan di dalam penelitian, maka pertanyaan penelitian yang akan dijawab melalui penelitian ini adalah sebagai berikut.

1. Apakah organizational culture berpengaruh terhadap employee engagement karyawan PT Pelindo III (PERSERO)?

2. Apakah organizational culture berpengaruh terhadap job satisfaction karyawan PT Pelindo III (PERSERO)?

3. Apakah job satisfaction berpengaruh terhadap employee engagement karyawan PT Pelindo III (PERSERO)?

4. Apakah job satisfaction memediasi hubungan organizational culture dengan employee engagement PT Pelindo III (Persero)?

\section{METODE PENELITIAN}

Penelitian ini merupakan penelitian dengan pendekatan kuantitatif. Pendekatan ini digunakan untuk pengujian hipotesis, di mana untuk menguji hipotesis tersebut digunakan variabel dengan data terukur serta akan menghasilkan kesimpulan yang dapat digeneralisasikan. Metode pengumpulan data menggunakan metode survei dengan cara pembagian kuesioner pada karyawan PT Pelindo III yang bekerja di Kantor Pusat Surabaya. Populasi dalam penelitian ini adalah seluruh karyawan PT Pelindo III (Persero) yang bekerja di Kantor Pusat Kota Surabaya sebanyak 488 orang. Pengambilan sampel adalah suatu proses yang dilakukan untuk memilih dan mengambil sampel secara benar dari suatu populasi, sehingga dapat digunakan sebagai wakil yang dapat mewakili populasi tersebut (Hair et al, 2014). Sedangkan teknik penelitian ini menggunakan Partial Least Square (PLS).

Tabel Sampel Kantor Pusat PT Pelindo III (Persero)

\begin{tabular}{|l|l|l|l|l|}
\hline \multirow{2}{*}{ Direktorat Kantor Pusat } & \multicolumn{2}{|c|}{ Populasi } & \multicolumn{1}{c|}{$\begin{array}{c}\text { Purposive } \\
\text { Sampling }\end{array}$} & Sampel \\
\hline \multirow{2}{*}{ Direktorat SDM } & Struktural & 40 & $(40 / 488) X 210$ & 17 \\
\cline { 2 - 5 } & Staf/Pelaksana & 114 & $(114 / 488) X 210$ & 49 \\
\hline \multirow{2}{*}{$\begin{array}{l}\text { Direktorat Operasi dan } \\
\text { Komersial }\end{array}$} & Struktural & 17 & $(17 / 488) X 210$ & 7 \\
\cline { 2 - 5 } & Staf/Pelaksana & 68 & $(68 / 488) X 210$ & 29 \\
\hline \multirow{2}{*}{$\begin{array}{l}\text { Direktorat Transformasi } \\
\text { Pengembangan Bisnis }\end{array}$} & Struktural & 13 & $(13 / 488) X 210$ & 6 \\
\cline { 2 - 5 } & Staf/Pelaksana & 40 & $(40 / 488) X 210$ & 17 \\
\hline \multirow{2}{*}{ Direktorat Teknik } & Struktural & 31 & $(31 / 488) X 210$ & 13 \\
\cline { 2 - 5 } & Staf/Pelaksana & 48 & $(48 / 488) X 210$ & 21 \\
\hline \multirow{2}{*}{ Direktorat Keuangan } & Struktural & 15 & $(15 / 488) X 210$ & 7 \\
\cline { 2 - 5 } & Staf/Pelaksana & 53 & $(53 / 488) X 210$ & 23 \\
\hline \multirow{2}{*}{ Sekretaris Perusahaan } & Struktural & 5 & $(5 / 488) X 210$ & 2 \\
\cline { 2 - 5 } & Staf/Pelaksana & 19 & $(19 / 488) X 210$ & 8 \\
\hline Satuan Pengawasan Intern & Struktural & 5 & $(5 / 488) X 210$ & 2 \\
\cline { 2 - 5 } & Fungsional & 20 & $(20 / 488) X 210$ & 9 \\
\hline Total & & 488 & & 210 \\
\hline
\end{tabular}

Sumber: Laporan Tahunan Direktorat SDM 2019, diolah

\section{ANALISIS DAN PEMBAHASAN HASIL PENE- LITIAN}

\section{Uji Validitas dan Reliabilitas}

Indikator dikatakan valid dan reliabel secara konstruk apabila mempunyai nilai faktor loading lebih besar atau sama dengan 0,5. Berdasarkan uji measurement model tersebut maka nilai outer loading dari masing-masing variabel dimana semua indikator sudah memenuhi syarat outer loading yaitu lebih besar dari 0,5, sehingga semua indikator dinyatakan layak untuk uji validitas dan reliabilitas. 
Rm. Kumara Anindhita Widyaswendra, Pengaruh Organizational Culture terhadap Employee Engagement dengan Job Satisfaction sebagai Variable Intervening pada Karyawan PT Pelindo III (Persero)

\section{Analisis Hasil PLS}

\section{Outer model (discriminant validity)}

Untuk tahap validitas diskriminan, pengukurannya dinilai berdasarkan cross loading pengukuran dengan konstruknya atau dengan membandingkan akar AVE untuk setiap konstruk dengan korelasi antara konstruk satu dengan konstruk lainnya dalam model. Suatu model dikatakan memiliki validitas diskriminan yang cukup apabila akar AVE untuk setiap konstruk lebih besar daripada korelasi antara konstruk dengan konstruk lainnya dalam model. Tabel di bawah akan menunjukkan nilai AVE dan akar AVE.

Tabel Nilai AVE dan Akar AVE

\begin{tabular}{|l|c|c|}
\hline & AVE & Akar AVE \\
\hline Organizational culture & 0.7438 & 0.8624 \\
\hline Employee engagement & 0.7351 & 0.8574 \\
\hline Job satisfaction & 0.7432 & 0.8621 \\
\hline
\end{tabular}

Sumber: Data Diolah, Lampiran 1

Selain melalui perbandingan nilai akar AVE dengan korelasi variabel laten, uji validitas diskriminan juga dapat dilakukan dengan melihat nilai cross loading. Kriteria dalam cross loading adalah bahwa setiap indikator yang mengukur konstruknya haruslah berkorelasi lebih tinggi dengan konstruknya dibandingkan dengan konstruk lainnya. Pada proses olah data seluruh variabel, organizational culture, employee engagement, dan job satisfaction semuanya memenuhi syarat di mana setiap indikator yang mengukur konstruknya telah berkorelasi lebih tinggi dengan konstruknya dibandingkan korelasi dengan konstruk lainnya.

\section{Convergent validity}

Pengujian convergent validity dari indikatorindikatornya bergantung dari jenis dari indikator itu sendiri. Dalam hal ini, item-item indikator dari masing-masing variabel bersifat reflektif sehingga apabila ada yang tidak valid maka item tersebut akan dieliminasi. Indikator dari masingmasing variabel dikatakan valid apabila nilai dari T-statistiknya adalah $\geq 1.96$.

Tabel Outer Loadings (Mean, STDEV, T-Values)

\begin{tabular}{|c|c|c|}
\hline & $\begin{array}{c}\text { Original } \\
\text { Sample }(\mathrm{O})\end{array}$ & $\begin{array}{c}\text { T Statistics } \\
(\mid \mathrm{O} / \text { STERR } \mid)\end{array}$ \\
\hline a1 <- Employee Engagement & 0,0624 & 8,7730 \\
\hline $\mathrm{a} 2<-$ Employee Engagement & 0,0718 & 20,1553 \\
\hline a3 <- Employee Engagement & 0,0704 & 21,7141 \\
\hline $\mathrm{a} 4<-$ Employee Engagement & 0,0700 & 22,1199 \\
\hline a5 <- Employee Engagement & 0,0647 & 12,9015 \\
\hline $\mathrm{c} 1<-$ Organizational Culture & 0,0709 & 19,3649 \\
\hline c2 $<-$ Organizational Culture & 0,0650 & 14,9965 \\
\hline c3 $<-$ Organizational Culture & 0,0704 & 21,6849 \\
\hline c4 <- Organizational Culture & 0,0679 & 17,4277 \\
\hline c5 <- Organizational Culture & 0,0635 & 10,5490 \\
\hline cf1 <- Organizational Culture & 0,0681 & 17,8906 \\
\hline cf $2<-$ Organizational Culture & 0,0686 & 17,0241 \\
\hline cf3 $<-$ Organizational Culture & 0,0558 & 8,8657 \\
\hline cf $4<-$ Organizational Culture & 0,0676 & 14,9745 \\
\hline cf5 $<$ - Organizational Culture & 0,0635 & 9,2394 \\
\hline cf6 $<-$ Organizational Culture & 0,0683 & 18,1764 \\
\hline cf7 <- Organizational Culture & 0,0723 & 18,0213 \\
\hline d1 <- Employee Engagement & 0,0803 & 11,5185 \\
\hline d2 <- Employee Engagement & 0,0750 & 20,2706 \\
\hline d3 <- Employee Engagement & 0,0779 & 18,2869 \\
\hline d4 <- Employee Engagement & 0,0772 & 14,3158 \\
\hline d5 <- Employee Engagement & 0,0736 & 17,1917 \\
\hline d6 <- Employee Engagement & 0,0819 & 18,2141 \\
\hline i1 <- Organizational Culture & 0,0597 & 17,4880 \\
\hline i2 <- Organizational Culture & 0,0588 & 15,5685 \\
\hline i3 <- Organizational Culture & 0,0530 & 9,0295 \\
\hline i4 <- Organizational Culture & 0,0622 & 13,9972 \\
\hline i5 <- Organizational Culture & 0,0596 & 12,8388 \\
\hline i6 <- Organizational Culture & 0,0620 & 12,6705 \\
\hline js1 <- Job Satisfaction & 0,1039 & 11,9782 \\
\hline js10 <- Job Satisfaction & 0,0995 & 11,3355 \\
\hline js2 <- Job Satisfaction & 0,1002 & 12,7935 \\
\hline js3 <- Job Satisfaction & 0,1219 & 15,7196 \\
\hline js4 <- Job Satisfaction & 0,1307 & 16,9529 \\
\hline js5 <- Job Satisfaction & 0,1140 & 16,8923 \\
\hline js6 <- Job Satisfaction & 0,1284 & 17,3743 \\
\hline js7 <- Job Satisfaction & 0,1211 & 16,0864 \\
\hline js8 <- Job Satisfaction & 0,1229 & 14,4505 \\
\hline js9 <- Job Satisfaction & 0,1135 & 17,0212 \\
\hline v1 <- Employee Engagement & 0,0546 & 9,0929 \\
\hline v2 <- Employee Engagement & 0,0720 & 18,4713 \\
\hline v3 <- Employee Engagement & 0,0790 & 24,2999 \\
\hline v4 <- Employee Engagement & 0,0750 & 23,0409 \\
\hline v5 <- Employee Engagement & 0,0776 & 19,6618 \\
\hline
\end{tabular}

Sumber: Data Diolah, Lampiran 1 


\section{Uji Reliabilitas}

Uji reliabilitas diperlukan untuk mengukur stabilitas dan konsistensi dari suatu instrumen dalam mengukur suatu konsep atau variabel. Pada penelitian ini, reliabilitas dapat diukur dengan melihat nilai composite reliability. Hair et al (2014) menyebutkan bahwa composite reliability mengukur nilai sesungguhnya reliabilitas suatu konstruk. Disebutkan juga bahwa untuk dapat dikatakan suatu konstruk reliabel, rule of thumb yang berlaku adalah $>0.7$ untuk nilai composite reliability. Hasil untuk uji reliabilitas penelitian ini dapat dilihat sebagai berikut.

Tabel Nilai Composite Realibility

\begin{tabular}{|l|c|}
\hline & Composite Reliability \\
\hline Organizational culture & 0.9812 \\
\hline Employee engagement & 0.9778 \\
\hline Job satisfaction & 0.9664 \\
\hline
\end{tabular}

Sumber: Hasil pengolahan dengan SmartPLS

\section{Pengujian Model Struktural (Inner Model)}

Pengujian selanjutnya dapat dilakukan dengan melihat nilai koefisien path atau inner model yang menunjukkan tingkat signifikansi dalam pengujian hipotesis. Dalam hal melihat signifikansi hubungan antar konstruk maka yang digunakan adalah analisis T-test dari koefisien jalur (path coefficient). Hubungan jalur antarvariabel tersebut dianggap signifikan jika memiliki T-statistics lebih dari 1,96.

Tabel Nilai Path Coeffisient (Mean, Standard Deviation, T-Values)

\begin{tabular}{|l|c|c|}
\hline & $\begin{array}{c}\text { Original } \\
\text { Sample (O) }\end{array}$ & $\begin{array}{c}\text { T Statistics } \\
(\mid \text { O/STERR } \mid)\end{array}$ \\
\hline $\begin{array}{l}\text { Organizational Culture -> } \\
\text { Employee Engagement }\end{array}$ & 0.2060 & 1.9445 \\
\hline $\begin{array}{l}\text { Organizational Culture -> } \\
\text { Job Satisfaction }\end{array}$ & 0.8056 & 20.7593 \\
\hline $\begin{array}{l}\text { Job Satisfaction -> } \\
\text { Employee Engagement }\end{array}$ & 0.6818 & 5.8720 \\
\hline
\end{tabular}

Sumber: Hasil pengolahan dengan SmartPLS
Pengaruh organizational culture terhadap employee engagement

Organizational culture yang kuat menunjukkan bahwa karyawan memegang keyakinan dan nilai-nilai etika yang sama. Ketika keyakinan dan nilai-nilai etika selaras dengan tujuan organisasi, mereka bisa efektif dalam membangun tim karena adanya hubungan dan kepercayaan membantu mereka menghindari konflik dan fokus pada penyelesaian tugas. Karyawan yang memaknai serta berkontribusi terhadap pekerjaannya dan mengerjakan pekerjaan dengan mencurahkan segenap energi fisik, kognitif, dan emosinya disebut sebagai karyawan yang engaged (Kahn, 1990 dalam Kulaar et al., 2008).

Membangun organizational culture yang khas merupakan salah satu strategi menciptakan employee engagement yang perlu untuk diperhatikan oleh para manajer, perusahaan harus mempromosikan organizational culture yang kuat di mana tujuan dan nilai-nilai manajer sejajar di semua bagian pekerjaan. Perusahaan yang membangun budaya saling menghormati dengan menjaga kisah sukses hidup tidak hanya akan menjaga karyawan mereka yang engaged, tetapi juga mereka karyawan yang baru masuk dapat menularkan budaya semangat untuk bekerja. Pelindo III sudah menerapkan organizational culture yang terdiri dari customer focus, care, dan integrity. Pada pelaksanaan di perusahaan para karyawan menunjukkan bisa bekerja dengan tim demi kepentingan pelanggan, di mana karyawan saling membantu ketika karyawan lain merasa kesulitan. Hal ini bisa dilihat dari jawaban responden memiliki nilai rata-rata tertinggi pada dimensi customer focus. Selain itu ada kesempatan belajar yang diberikan oleh Pelindo bagi karyawan untuk pengembangan kompetensi bagi karyawannya. Pelindo juga memberikan beasiswa kepada karyawannya buat melanjutkan studi lebih lanjut. 
Dari dua alasan ini bisa membuat karyawan akan lebih engage pada perusahaan.

Pengaruh organizational culture terhadap job satisfaction

Menurut Kotter dan Hesket (Sutanto, 2002: 129) mengungkapkan bahwa organizational culture yang kuat akan memicu karyawan untuk berpikir, berperilaku dan bersikap sesuai dengan nilai-nilai organisasi. Kesesuaian antara organizational culture dengan anggota organisasi yang mendukungnya akan menimbulkan job satisfaction, sehingga mendorong karyawan untuk meningkatkan kinerja menjadi lebih baik, yaitu bertahan pada satu perusahaan dan berkarier dalam jangka panjang. Oleh karena itu, organizational culture yang kuat diperlukan oleh setiap organisasi agar kepuasan karyawan meningkat.

Hal tersebut selaras dengan penelitian yang dilakukan oleh Safwat, Ahmad (2015) yang menunjukkan bahwa organizational culture memiliki pengaruh positif yang signifikan terhadap job satisfaction. Penelitian tersebut juga didukung oleh penelitian yang dilakukan Ahamed dan Mahmood (2015) yang menyimpulkan bahwa organizational culture benar-benar memiliki pengaruh yang kuat dan signifikan terhadap job satisfaction.

\section{Pengaruh job satisfaction terhadap employee engagement}

Seseorang dengan tingkat job satisfaction yang tinggi memiliki perasaan-perasaan positif tentang pekerjaan tersebut, sementara seseorang yang tidak puas memiliki perasaan-perasaan yang negatif tentang pekerjaan tersebut. Orang yang merasa puas menganggap kepuasan sebagai suatu rasa senang dan sejahtera karena dapat mencapai suatu tujuan atau sasaran. Setiap pimpinan per- usahaan perlu mengetahui informasi mengenai kepuasan karyawannya dalam bekerja secara akurat sebagai bahan pertimbangan dalam mengambil keputusan untuk memecahkan masalah yang dihadapi dalam perusahaan.

Untuk mendorong keterlibatan karyawan, organisasi harus fokus pada menumbuhkan lingkungan kerja yang mendukung karyawan, membuat mereka termotivasi dan positif, tidak hanya tentang pekerjaan mereka saja tetapi juga tentang organisasi secara keseluruhan. Dengan menawarkan kepemimpinan berkualitas tinggi dalam lingkungan kerja yang bijaksana dan teratur, organisasi dapat meningkatkan tingkat employee engagement yang diinginkan. Safwat, Ahmad (2015) dalam penelitiannya menyimpulkan bahwa ada hubungan positif antara variable job satisfaction dengan employee engagement, yang dapat diartikan bahwa employee engagement dapat ditingkatkan dengan meningkatkan job satisfaction karyawan. Pininta dan Indriati (2015) dalam penelitiannya juga menyimpulkan bahwa ada hubungan positif yang signifikan antara job satisfaction terhadap employee engagement, yang artinya bahwa semakin tinggi job satisfaction semakin tinggi employee engagement

\section{Job satisfaction memediasi hubungan organiza- tional culture dengan employee engagement PT Pelindo III (Persero)}

Pada penelitian ini selain menguji pengaruh langsung juga menguji pengaruh tidak langsung. Pada hipotesis ketiga yang mengemukakan bahwa organizational culture berpengaruh terhadap employee engagement melalui job satisfaction dapat diterima. Hasil yang diperoleh menunjukkan bahwa job satisfaction memediasi secara penuh pengaruh organizational culture yang berpengaruh terhadap employee engagement. 
Beberapa faktor penting yang lebih banyak mendatangkan job satisfaction yang pertama adalah pekerjaan yang memberikan kesempatan untuk menggunakan keterampilan, dan umpan balik tentang seberapa baik mereka bekerja, faktor berikutnya adalah bagaimana kondisi kerja karyawan, baik dari segi kenyamanan pribadi maupun kemudahan untuk melakukan pekerjaan, hal-hal tersebut berkaitan erat dengan aturan dan standar-standar yang telah ditentukan oleh perusahaan, sedangkan aturan dan standar tersebut terbentuk dari organizational culture di dalam perusahaan itu sendiri. Apabila persepsi karyawan terhadap organizational culture baik, maka karyawan akan merasa puas terhadap pekerjaannya. Sebaliknya, apabila persepsi karyawan terhadap organizational culture tidak baik, maka karyawan cenderung tidak puas terhadap pekerjaannya. Hal ini bisa dilihat koefisien estimate bahwa budaya organisasi memberikan kontribusi yang besar pada kepuasan karyawan. Penerapan budaya Pelindo sudah memberikan dampak yang signifikan bagi karyawan yang meliputi customer focus, care dan integrity bisa diterima oleh karyawan Pelindo. Budaya yang ada sebaiknya dipertahankan agar tingkat kepuasan karyawan tetap tinggi, ketika tingkat kepuasan yang dimiliki tinggi maka akan semakin engage pada perusahaan. Selain itu para karyawan yang masih berusia produktif juga bisa menyesuaikan dengan budaya yang diterapkan perusahaan.

Dalam penelitian yang dilakukan Humairoh dan Wardoyo (2017) menunjukkan terdapat pengaruh dan signifikan antara organizational culture terhadap employee engagement dengan job satisfaction sebagai variabel intervening. Dengan hasil ini maka dapat disimpulkan bahwa job satisfaction menjadi variabel antara organizational culture terhadap employee engagement atau adanya organizational culture dalam bekerja akan menumbuhkan rasa puas dalam bekerja dan rasa puas yang dirasakan ini akan berpengaruh terhadap terciptanya keterikatan yang baik dari para karyawan.

\section{SIMPULAN DAN SARAN}

\section{Simpulan}

Tujuan dilakukannya penelitian adalah untuk menguji pengaruh organizational culture terhadap employee engagement dengan job satisfaction sebagai variabel antara (intervening variable). Dari hasil analisis yang dilakukan, berikut kesimpulan yang telah didapatkan.

a. Organizational culture berpengaruh signifikan terhadap employee engagement. Hal tersebut menunjukkan di mana ketika organizational culture semakin tinggi, maka employee engagement juga akan meningkat.

b. Organizational culture berpengaruh signifikan terhadap Job satisfaction. Hal tersebut menunjukkan di mana ketika organizational culture semakin tinggi, maka job satisfaction juga akan meningkat.

c. Job satisfaction berpengaruh signifikan terhadap employee engagement, yang artinya bahwa semakin tinggi job satisfaction semakin tinggi employee engagement.

d. Job satisfaction memediasi secara penuh pengaruh organizational culture yang berpengaruh terhadap employee engagement.

\section{Saran}

Dari hasil analisis yang dilakukan, berikut implikasi manajerial dan akademis dari penelitian yang dapat diterapkan pada perusahaan.

a. Bahwa job satisfaction menjadi variabel antara organizational culture terhadap employee engagement atau adanya organizational culture dalam bekerja akan menumbuhkan rasa 
Rm. Kumara Anindhita Widyaswendra, Pengaruh Organizational Culture terhadap Employee Engagement dengan Job Satisfaction sebagai Variable Intervening pada Karyawan PT Pelindo III (Persero)

puas dalam bekerja dan rasa puas yang dirasakan ini akan berpengaruh terhadap terciptanya keterikatan yang baik dari para karyawan. Begitu pentingnya faktor organizational culture, maka meski dari hasil penelitian di PT Pelindo III (Persero) menunjukkan telah Tinggi, namun faktor ini harus terus menerus ditingkatkan, khususnya pada aspek dalam bekerja perusahaan memberikan toleransi kepada karyawan yang bersikap jujur dan terbuka pada situasi apa pun di perusahaan.

b. Bahwa employee engagement menunjukkan telah tinggi, namun terlihat dari penilaian yang perlu menjadi perhatian adalah bahwa karyawan merasa bahwa sebagian besar waktu mereka terserap untuk pekerjaan, untuk itu perlu dievaluasi work instruction, standard operating procedure dan peraturan direksi tentang kewenangan pekerjaan masing-masing karyawan serta mereviewnya secara periodik untuk kemudian dibuat analisis beban kerja yang tepat.

c. Job satisfaction dari masing-masing karyawan PT Pelindo III (Persero) sudah Tinggi dan faktor kesempatan pengembangan diri pada pekerjaan menempati kategori tertinggi dari faktor lainnya, untuk itu perusahaan hendaknya selalu konsisten untuk mempertahankan hal ini, terutama mengingat mayoritas karyawan PT Pelindo III (Persero) adalah generasi millennial sehingga harus dicari programprogram yang sesuai dengan minat mereka, karena terbukti dari program pengembangan karier serta kesempatan belajar baik di dalam negeri maupun luar yang dilakukan oleh perusahaan direspons baik oleh karyawan.

d. Pada penelitian ini banyak sekali faktor atau variable yang memengaruhi employee engagement yang masih belum dapat dimasukkan dalam variabel penelitian dikarenakan adanya beberapa keterbatasan data. Sehingga untuk langkah berikutnya peneliti memberikan saran kepada pihak akademisi untuk dapat mengusulkan penelitian dengan topik penelitian dengan variabel intervening lain yang berpengaruh langsung pada peningkatan $\mathrm{em}$ ployee engagement.

\section{DAFTAR RUJUKAN}

Agarwal, P. \& Sajid, S.M. 2017. “A Study of Job Satisfaction, Organizational Commitment and Turnover Intention among Public and Private Sector Employees". Journal of Management Research, Vol. 17. No. 3. pp. 123-136.

Ahamed, Maruf., Mahmood, Rezwan. (2015). "Impact of Organizational Culture on Job Satisfaction: A Study on Banglalion Communication Ltd, Bangladesh”. European Journal of Business and Management, Vol.7, No.10.

Augusty, Ferdinand. 2006. "Metode Penelitian Manajemen”. Semarang: Badan Penerbit Universitas Diponegoro.

Barney, J.B. 1991. "Firm resources and sustained competitive advantage". Journal of Management, Vol. 17, No. 1, pp. 19-120. Jewel, L.N. \& Siegel Marc. 1998. "Psikologi Industri/Organisasi Modern”. Penerjemah, A. Hadyana Pudjaatmaka dan Maetasari. Jakarta: Penerbit Archan.

Khan, et al. 2011. "Impact of Organization Culture on the Job Satisfaction of the Employees (Banking Sector of Pakistan)”. European Journal of Economics, Finance and Administrative Sciences, Issue, 35, pp. 7-14.

Kreitner, Robertdan Kinicki, Angelo. 2010. “Organizational Behavior Ninth Edition”. New York: McGraw-Hill International Edition. 
Lintangsari, Amanda Ayu, Aditya, Munawir Yusuf, \& Priyatama, Nanda. 2015. Hubungan antara Employee Satisfaction dan Budaya Organisasi dengan Employee Engagement pada Karyawan Tetap PT BPD Jawa Tengah Cabang Utama Semarang. Program Studi Psikologi Fakultas Kedokteran Universitas Sebelas Maret.

Lockwood, R.N. 2007. Leveraging Employee Engagement for Competitive Advantage. Virginia: Society for Human Resource Management.

McBain, R. 2007. "The Practice of Engagement: Research into Current Employee Engagement Practice”. Strategic HR Review, 6(6), 124-136.

Mohammed Al Shehri, Patrick McLaughlin, Ahmed Al-Ashaa, \& Rashid Hamad. 2017. "The Impact of Organizational Culture on Employee Engagement in Saudi Banks”. Journal of Human Resources Management Research http://ibimapublishing.com/articles/JHRMR/2017/761672, Article ID 761672, pp. 23.

Robbins, Stephen P. \& Timothy A. Judge. 2008. Perilaku Organisasi, Edisi 12 Jilid 1 dan 2. Jakarta: Salemba Empat.

Robbins, Stephen P. 2007. Perilaku Organisasi Konsep, Kontroversi, Aplikasi. (Alih Bahasa: Hadyana Pujaatmaka dan Benyamin Molan; Editor. Agus Widyantoro) Edisi 8. Jakarta: Prenhallindo.

Robbins, Stephen P. 2002. Prinsip-Prinsip Perilaku Organisasi. Edisi Kelima. Alih Bahasa: Ha- lida, Dewi Sartika. Jakarta: Penerbit Erlangga.

Sayeeduzzafar Qazi, Tejbir Kaur P. 2017. Impact of Organizational Culture on Job Satisfaction among the University Faculty Members - An Empirical Study. International Journal of Business and Social Science, Vol. 8, No. 3.

Seijts, G., \& Crim, D. 2006. What Engages Employees the Most or, the Ten C's of Employee Engagement. Ivey Business Journal Online, 1-5.

Sugiyono. 2007. Metode Penelitian Bisnis. Bandung: Alfabeta.

Sugiyono. 2010. Metode Penelitian Administrasi. Bandung: Alfabeta.

Sugiyono. 2011. Metode Penelitian Kuantitatif, Kualitatif, dan R\&D. Bandung: Afabeta

Sugiyono. 2012. Metode Penelitian Kuantitatif, Kualitatif, dan RひoD. Bandung: Alfabeta.

Thomas, C.H. 2007. A New Measurement Scale for Employee Engagement: Scale Development, Pilot Test and Replication. Academy of Management.

Wibowo, M.A. \& Putra, Y.S. 2016. Pengaruh Motivasi dan Budaya Organisasi terhadap Kepuasan Kerja Serta Implikasinya terhadap Kinerja Karyawan pada Rumah Sakit Umum (RSU) Salatiga. Among Makarti, Vol. 9, No. 17.

Zikmund, W.G., Babin, B.J., Carr, J.C., \& Griffin, M. 2013. Business Research Method". 9 ${ }^{\text {th }}$ International Edition. Canada: Cengage Learning. 